\title{
Rejoinder from sociability to solidarity: reply to commentators
}

\author{
Will Kymlicka
}

Correspondence:

kymlicka@queensu.ca

Canada Research Chair in Political

Philosophy Department of

Philosophy, Queen's University,

Kingston, ON K7L 3N6, Canada
I'd like to thank my commentators for their insightful and challenging replies. My aim in the paper was to stimulate creative thinking about solidarity in diverse societies, and these seven comments represent exactly the sort of constructive analyses I was hoping to prompt.

I can't address all of the issues raised by the commentators, but let me begin by emphasizing that my concern is with social justice, which I take to be a much more ambitious goal than simply hospitality, "conviviality" or "everyday sociability", in Glick Schiller terms. I take it as a given that people of different ethnic and religious backgrounds are perfectly capable of living sociably as neighbours: in fact, humans have always done so. We clearly do not need national solidarity to generate this capacity.

But I do not believe that everyday sociability is sufficient to achieve social justice, or to build and sustain a redistributive welfare state. Social justice, at least as understood within the social-democratic/liberal-egalitarian tradition ${ }^{1}$, requires not just the civilities and hospitalities of everyday life, but a commitment to building a society of equals, which in turn requires active state measures to address unchosen disadvantages in people's life chances. The recent explosive rise in inequality across the Western societies indicates that we are moving farther and farther from this goal.

So the central challenge of social justice as I see it is not how to enable people to live together peacefully as neighbours, but rather how to mobilize people to support policies that address disadvantage. And the most cursory glance at human history would indicate that the existence of everyday sociability does not, by itself, generate a commitment to social justice in this robust sense. Throughout human history, everyday civilities have gone hand-in-hand with acceptance of deep social stratification. In my paper, I argued that this should not be surprising, since everyday sociability rests on a different normative logic than that of a social-democratic welfare state: an ethic of hospitality and conviviality is not the same as an ethic of social justice. Glick Schiller clearly disagrees with this: she thinks that everyday sociabilities are sufficient to sustain a commitment to social justice. But she gives no evidence for this claim, and does not address my argument that they rest on a different normative logic.

Her focus on the importance of local-level conviviality is shared by other commentators (eg., Bauböck \& Engbersen), and is a central trope in the recent European literature on city-level interculturalism (eg., Zapata-Barrero, 2011; Oosterlynck, Loopmans, Schuermans, Vandenabeele, \& Zemni, 2016). But the existence of convivial neighbourhoods tells us nothing about whether state policies regarding health care, education,

(C) 2016 The Author(s). Open Access This article is distributed under the terms of the Creative Commons Attribution 4.0 International License (http://creativecommons.org/licenses/by/4.0/), which permits unrestricted use, distribution, and reproduction in any medium, provided you give appropriate credit to the original author(s) and the source, provide a link to the Creative Commons license, and indicate if changes were made. 
naturalization, official languages, labour markets, taxes and social benefits operate to reduce disadvantages. In fact, the existence of convivial neighbourhoods is fully compatible with - perhaps even the hallmark of - neoliberal multiculturalism. In this respect, the new European rhetoric of local-level interculturalism seems distressingly similar to the old 1990s rhetoric of neoliberal multiculturalism ${ }^{2}$. They both privilege interaction across ethnic and religious lines at the local level and in civil society, as a means of increasing comfort with, and reaping the benefits of, cultural diversity, while ignoring the deeper economic, political and social structures of liberal-democratic nation-states that generate disadvantage ${ }^{3}$.

Perhaps the state of inter-ethnic relations in some European cities is so dire that the best we can hope for is to achieve civility and sociability. Or perhaps cities are the only promising space for pro-diversity initiatives, given the power of anti-immigrant parties at the national level. If so, the focus on local initiatives makes strategic sense. But we should not exaggerate what can be achieved at the local level, or what we lose by giving up on national level policies. While the progressive defenders of diversity are fighting for intercultural neighbourhoods and intercultural cities, conservatives are defining the agenda around national security, national citizenship, national solidarity and national identity - all in ways that systematically marginalise and stigmatise minorities. Local victories will be both limited and fragile unless the national agenda can be reframed through a progressive multicultural vision of nationhood. Indeed, some commentators argue that insofar as the intercultural cities agenda in Europe seeks to bypass rather than directly challenge the securitized national discourse around migration, it lacks transformative potential, serving at best to manage securitization ${ }^{4}$.

Certainly in the Canadian context, constricting our vision to local conviviality would be a regression. Canadians like to believe that we excel at everyday sociability in interethnic contexts, and the cross-national evidence suggests that Canadians are indeed unusually comfortable with diversity in everyday settings (Kymlicka, 2010). But the extent to which this everyday sociability in Canada is matched by a commitment to social justice has varied enormously, and my concern is how to motivate the latter.

So my interest is: what more, or what else, is needed to sustain a commitment to social justice, beyond everyday sociability? And my suggestion in the paper was that (1) nationhood has helped in the past to underpin this commitment; and (2) nationhood can continue to play this role, even in the face of growing diversity, so long as it is reconceived in a multicultural manner. Glick Schiller disputes the former claim, which she describes as a "communitarian just-so story". Most of the commentators, however, accept the former claim, but express a range of doubts about the latter. Nationhood, they suggest, may have worked in the past, but it can no longer serve this function, and/or it cannot be reconceived in multiculturalist terms.

I cannot respond in depth to all of the doubts, but I would like to respond to one in particular. According to Engbersen, multiculturalism does not work in an era of liquid mobility, where more and more residents are temporary or "floating populations", with variable and precarious legal statuses. Multiculturalism, he suggests, might have worked in an era when there was a finite number of immigrant groups all of whom settled permanently, but cannot work in an era of transient flows coming and going in all directions.

I agree that liquid mobility puts multicultural approaches under intense strain. But I think liquid mobility puts all prevailing models under strain, and it's not clear what 
alternatives would fare better. Engbersen himself suggests that multiculturalism policies are being replaced by "general policies aimed at all citizens" and by "civic integration policies", but he does not explain how either of these actually helps deal with the challenges of liquid mobility. So far as I can tell, both civic integration policies and general citizenship policies are as rooted in the idea of permanent settlement as multiculturalism policies. Indeed, Engbersen himself notes that transient populations are typically exempted from the requirements of these general integration/citizenship policies, both in Canada and in Europe.

So why then do we see increased reliance on general citizenship policies and civic integration policies, despite the rise of liquid mobility? The answer, I would argue, is that many migrants do settle permanently. Contrary to the image of liquid mobility, we are not all refugees or floating populations. Many migrants settle and become long-term stakeholders in their new society. And so it remains a vital task of a democratic state to figure out the appropriate terms of long-term integration into the host society. Both multiculturalism policies and civic integration policies are a response to that task, but they differ in how they understand the fair terms of integration. According to the study Engbersen himself relies on, the shift from multiculturalism to civic integration involves "placing greater responsibility on the individual immigrant for their own integration" (Scholten, Collet, \& Petrovic, 2016). Exactly so: the shift from multiculturalism to civic integration is not about how best to deal with liquid mobility; it is about how to allocate the burdens and responsibilities of long-term integration. And I would argue that most civic integration policies are simply unfair in the terms of integration they offer (Banting \& Kymlicka, 2013). Moreover, as I suggested in my paper, they also tend to reproduce harsh judgements about the deservingness of immigrants, which is a fundamental obstacle to inclusive solidarity. So they are unfair in and of themselves, and have knock-on effects in undermining a sense of mutual obligation.

Engbersen acknowledges that civic integration policies are likely to create "specific migrant groups that are in vulnerable positions" and who will face challenges to "enable their transition from non- or partial membership to full social membership". That is indeed the challenge, and my argument is that coercive civic integration policies worsen the problem, whereas multicultural nationhood can help. Engbersen appears to disagree, but I don't yet see his argument for rejecting multicultural nationhood, or his alternative to it. In any event, I think the issue of liquid mobility and floating populations is a bit of a red herring. Insofar as the fundamental policy choice is between multiculturalism policies and civic integration policies, both options lay out the terms of integration for people with the right to stay and to settle long-term, and both need to be evaluated for their intrinsic fairness and for their impact on an ethos of solidarity ${ }^{5}$.

I have focused in this reply on the critiques that seemed most in opposition to my approach. I should say, however, that I'm pleased to note that other commentators are more sympathetic to the idea of a multicultural national solidarity, at least as an aspiration, even if they raise cogent questions about the politics of multicultural nationhood. I view the commentaries by Bauböck, Bloemraad, Kriesi, and Meer as all providing constructive amendments to my (sketchy) political story, and I'm inclined to simply accept most of their suggested amendments, as well as their sober assessment of the political challenges we face. As Kriesi notes, the challenge of reconciling multiculturalism and nationhood is connected to a much deeper challenge afflicting the social-democratic 
left: namely, the growing gap between the socially liberal professional elites who run social democratic parties and their traditional working-class supporters who are more socially conservative. The ideas of multiculturalism and national solidarity may be quite compatible at a theoretical level, but these ideas do not exist in a philosophical vacuum: they are carried into politics and championed by different sectors of the population, with different priorities and interests. Much has been written about how to overcome that gap, to which I have little to add, except to take some solace from the historical reminders that Bloemraad and Meer provide us. As they note, there was nothing automatic or smooth about creating national solidarities in the first half of the twentieth century, in the face of powerful class cleavages, strong localisms, and sectarian differences (eg., between Protestants and Catholics), even in a period of relatively low immigration. As Meer rightly puts it, "deep diversity is not the preserve of ethnic and migration-related difference". Yet the social-democratic left did succeed in building national solidarities, in spite of - and indeed partly through - the political conflicts generated by this project. And like Kriesi, I believe that a healthy dose of "enlightened understanding, empowerment and leadership" can help to sustain and reframe those solidarities in a multicultural direction.

\section{Endnotes}

${ }^{1}$ I defend this liberal egalitarian conception of justice, and its convergence with social-democratic views, in Kymlicka 2002. Favell suggests that my dismissive comments about neoliberalism raise doubts about my liberal credentials. I cannot fully address that charge here, except to say that I share the core liberal commitment to the right of individuals to decide for themselves what sort of life is worth leading, and as a corollary, a commitment to the constitutional protection of a set of basic civil and political liberties. This anti-paternalistic and anti-perfectionist commitment is shared by all liberals, left or right. What defines the left-liberal view is that a liberal state must also remedy unchosen disadvantages. This is the fundamental point of disagreement with libertarianism (as a political philosophy) and neoliberalism (as a political agenda). Having said that, I accept Favell's point that the expansion of mobility rights and nondiscrimination rights within the EU should be seen as an accomplishment, from any liberal perspective, and not discounted by simply labelling it as "neoliberal". And I accept Bauböck's point that obligations of global justice constrain state prerogatives to regulate admissions. Trying to achieve social justice through closed borders is therefore neither morally permissible nor practically feasible. This is precisely why, on my view, we need to reconcile multiculturalism and solidarity.

${ }^{2}$ On the celebration of local conviviality as the hallmark of neoliberal multiculturalism, see Murphy, O’Brien, \& Watson, 2003.

${ }^{3}$ Or so I argue in Kymlicka, 2016.

${ }^{4}$ Alkopher (2015). For another discussion of the limits of promoting local interculturalism in the face of national-level indifference or hostility, see Downing 2015.

${ }^{5}$ From very different directions, the commentaries by Glick Schiller and Favell both suggest that if we have really moved from an age of migration to an age of mobility, then the choice is not civic integration versus multiculturalism, but some entirely new post-national constellation. 
Received: 23 March 2016 Accepted: 25 March 2016

Published online: 20 June 2016

\section{References}

Alkopher, T. D. (2015). The political psychology of integration strategies: the case of the European Commission's interculturalism. Journal of International Relations and Development, 18(4), 428-454.

Banting, K., \& Kymlicka, W. (2013). Is there really a retreat from multiculturalism policies? New evidence from the multiculturalism policy index. Comparative European Politics, 11(5), 577-598.

Downing, J. (2015). European influence on diversity policy frames: paradoxical outcomes of Lyon's membership of the Intercultural Cities programme. Ethnic and Racial Studies, 38(9), 1557-1572.

Kymlicka, W. (2002). Contemporary Political Philosophy. Oxford: Oxford University Press.

Kymlicka, W. (2010). Testing the liberal multiculturalist hypothesis: normative theories and social science evidence. Canadian Journal of Political Science, 43(2), 257-271.

Kymlicka, W. (2016). Defending diversity in an era of populism: multiculturalism and interculturalism compared. In N. Meer, T. Modood, \& R. Zapata-Barrero (Eds.), Multiculturalism and interculturalism: debating the dividing lines. Edinburgh: Edinburgh University Press.

Murphy, P., O'Brien, B., \& Watson, S. (2003). Selling Australia, selling Sydney: the ambivalent politics of entrepreneurial multiculturalism. Journal of International Migration and Immigration, 4, 471-498.

Oosterlynck, S., Loopmans, M., Schuermans, N., Vandenabeele, J., \& Zemni, S. (2016). Putting flesh to the bone: looking for solidarity in diversity, here and now. Ethnic and Racial Studies, 1-19. doi:10.1080/01419870.2015.1080380.

Scholten, P., Collet, E. \& Petrovic, M. (2016). Mainstreaming migrant Integration? A critical analysis of a new trend in integration governance. International Review of Administrative Sciences. OnlineFirst, March 30, 2016. doi:10.1177/ 0020852315612902

Zapata-Barrero, R. (2011). 'Anti-immigration populism: can local intercultural policies close the space?', Discussion paper. London: Policy Network.

\section{Submit your manuscript to a SpringerOpen ${ }^{\circ}$ journal and benefit from:}

- Convenient online submission

- Rigorous peer review

- Immediate publication on acceptance

- Open access: articles freely available online

- High visibility within the field

- Retaining the copyright to your article 